acknowledge the fact and deal with it. We reject the story, just as we would reject a person in real life".

Hulle is by my wete die enigstes wat hulle op skrif so positief uitlaat. Ek onderskryf graag hierdie woorde en behou daarmee vir my die reg voor om indien nodig 'n literêre kunswerk te mag verwerp of te kritiseer op grond van bo- of buiteestetiese Skrifgefundeerde norme, al word sulke maatstawwe dan vandag nog meestal beskou as ingesmokkelde kontrabande. P.U. vir C.H.O., P. D. van der Walt. Potchefstroom.

\title{
GEOLOGIESE TYD OF OSEAANDIEPTE?
}

Die fossielelae van die paleontologie skep vir die natuurwetenskaplike sowel as die teoloog oënskynlik onoorbrugbare vraagstukke. Vir die natuuruetenskaplike spreek dit van kronologiese opeenvolging van lewe op aarde ooreenkomstig 'n patroon wat oor die algemeen dui op 'n miljoene jare-proses van die primitiefste tot die mees ingewikkelde bouvorms. Hierdie verskynsel suggereer al dadelik die waarskynlikheid van ' $n$ deurlopende evolusieproses wat oor miljarde jare voltrek is. Die belangrikste vraagstuk waarvoor aanhangers van so 'n teorie te staan kom, is die algehele afwesigheid van oorgangsvorme wat tussen dic verskillende fossielelae moes gevind gewees het indien daar sprake was van genetiese verband. Op die verskillende uitvlugte hoef hier nie ingegaan te word nie, behalwe om prof. J. Lever aan te haal wat verklaar dat indien so 'n proses wel plaasgevind het, dit geskied het op 'n uyse wat vir die wetenskaplike tans nog onbekend is.')

Dat evolusic tussen soorte plaasgevind het, bly dus onbewese. Wat oënskynlik egter wel vasstaan, is dat die ouderdom van lewe op aarde in miljoene jare bereken moet word indien uitgegaan word van geologiese tydberekening. Dat hierdie berekening gegrond is op die evolusie-opvatting, moet rekening mee gehou word. Dit berus enersyds op Lyell se aktualiteitsbeginsel wat 'n voortdurende en geleidelike proses op geologiese gebied veronderstel waarbinne die evolusieproses voltrek sou word, en andersyds op ouderdomsbepaling van aardlae deur middel van hul fossiele-inhoud, wat inhou dat 'n skatting gemaak word ooreenkomstig 'n veronderstelde evolusieproses, waarvan die aard - en gevolglik ook die duur - tot hede toe nog steeds 'n saak van loutere spekulasie bly.

Krumbein verklaar in 1963 in verband hiermee as volg: 
,At the present time, no accurate method for determining the absolute age of sediments is available... The most widely applied approach is... based on the progressive change of organisms with geologic time".2) En in verband met die tydstratigrafiese eenhede merk hy op: "These units are not selfevident nor directly observable; rather, they are inferential and are the result of complex intellectual and philosophic processes". So betreklik is hierdie ouderdomsbepalings inderdaad dat bogenoemde outoriteit erken: „Equally qualified observers following different paths of deduction and inferential reasoning can come to quite different, although equally sound, conclusions as to the age of the strate and positions of time-stratigraphic boundaries". ${ }^{3}$ )

Daarom verbaas dit 'n mens ook nie dat Lyell se uniformitarianistiese uitgangspunt toenemende teenstand begin ondervind as gevolg van verdere ontdekkings nie, soos o.a. blyk uit standpunte wat gedurende die Amerikaanse Geologiese Instituut se kongres in 1963 ingeneem is en deur die paleontoloog, Norman Newell, direkteur van die Amerikaanse Museum van Natuurgeskiedenis, as volg weergegee is: „Geology suffers from a great lack of data and in such a situation, any attractive theory that comes along is taken as gospel. That is the case with uniformitarianism. Geology students are taught that the present is the key to the past, and they often take is to mean that nothing ever happened that isn't happening now. But since the end of World War II, when a new generation moved in, we have gathered more data and we have begun to realize that there were many catastrophic events in the past, some of which happened just once".")

Ons tweede gevolgtrekking is dan dat die tydberekenings van die geologie en paleontologie nie as volstrekte waarhede aanvaar kan word nie.

\section{Vrangstuk van Teologie}

Hierdie tydberekening skep vir die teoloog 'n gedugte vraagstuk by die verklaring van Genesis I, wat in samehang met Psalm 33 (,Hy het gespreek en dit was; Hy het gebied en dit staan") nie plek skyn te bied aan miljoene jare-tydperke nie. Sulke lang tydperke, indien hulle aanvaar moet word, bring mee of aanvaarding van 'n algemene evolusie as skeppingsmetode, òf so 'n radikale wysiging van die sesdaagse 
skepping van Genesis I dat dit met bestaande belydenisskrifte bots.

Die verskillende eksegetiese pogings wat rekening met hierdie lang tydperke wil hou, pleit op allerlei gronde vir die een of ander uitleg wat Genesis I o.a. nie letterlik opneem in sover dit sy volgorde en die lengte van sy dae betref nie

Diegene onder die eksegete wat geredelik die moontlikheid van die een of ander graad van evolusie aanvaar, kom natuurlik te staan voor dieselfde probleem wat die paleontoloog tot stilstand dwing: die algehele afwesigheid van oorgangsvorme.

Diegene wat evolusie verwerp of buite rekening laat, en hulle slegs laat lei deur die lang tydperke, word voor die paradoks gestel dat hulle ò die paleontologiese gegewens ten opsigte van opeenvolgende fossiele-lae moet verwerp, ò evolusie as skeppingsmetode moet aanvaar. Die paleontologie leer naamlik dat nie alleen die sedimentêre rotslae waarin organiese argiefstukke bewaar is, soms miljoene jare in ouderdom van mekaar verskil nie, maar dat die argiefstukke wat hulle bevat, self soms so radikaal van mekaar in bouvorm verskil dat aangeneem moet word dat die een groep uitgesterf het voordat die volgende (waarneembare) verskyn het..$^{5}$ ) Reeds Darwin het met hierdie vraagstuk geworstel, omdat dit by uitstek hierdie verskynsel is wat spreek van die ontbrekende oorgangsvorme.

Wanneer nou die teoloog wat evolusie verwerp, hom stel op die moontlikheid van miljoene-jaartydperke, moet hy aanvaar dat God aan die begin van elke skeppingsdag deur sy spreke voorvaderlike verteenwoordigers van alle soorte skepsele behorende tot daardie skeppingsdag onmiddellik in die lewe geroep het, wat dan oor miljoene jare vermenigvuldig het - waarby mikro-evolusie (ontwikkeling binne soorte) misken nie noodwendig uitgesluit hoef te wees nie. Maar dan kan nie tegelyk 'n skeppingspatroon aanvaar word, soos die paleontologie voorhou, wat sommige organiese tipes miljoene jare ná en onafhanklik van voorafgaande tipes vir die eerste maal laat verskyn nie, tensy elke fossiele-laag of bio-stratigrafiese eenheid self ' $n$ skeppingsdag verteenwoordig, sodat God by die aanvang van elke geologiese tydeenheid opnuut moes gespreek en geskep het. Of daar kan aangeneem uord dat God se spreke 'n vertraagde aksie kon ingehou het wat miljoene jare lank sou duur. Maar in daardie geval (afgesien 
van ander besware) hoef God ook maar net heel aan die begin, of byvoorbeeld aan die begin van die vyfde dag te gespreek het - want wat anders skei die vyfde van die sesde dag indien dit nie ,aand en môre" en ook nie God se spreke is nie?

Die sesdaagse skepping en sy verband met die vierde gebod kom dus in die gedrang. Daar was of minder skeppingsdae as ses - wat blykbaar vir die kaderteorie aanneemlik is - of daar was veel meer as ses, wat vir enigiemand wat nog meer as blote kerugma in Genesis I wil sien, onaanneemlik is.

Dit dan wat die vraagstukke betref waarvoor die paleontologie met sy kronologiese opvatting sowel die natuurwetenskaplike as die Skrifgelowige stel. Almal soek die oplossing binne die paleontologiese tydspatroon.

\section{Diepte in plaas van tyd}

Lê die oplossing nie buite die paleontologiese natuurvertolking nie? Laat ons 'n moontlikheid aan die hand doen. Indien die fossiele-lae nie in terme van tyd nie, dog in terme van diepte gesien word, verval al bogenoemde vraagstukke. Diepseekundiges het in die afgelope paar dekades bevind dat die lewe in die oseaan in vaste sones ingedeel is met 'n stygende lyn van meer primitief tot meer ingewikkelde bouvorme van onder na bo. Die Moskouse bioloog, Zenkewitz, skryf hierdie verskynsel toe aan die feit dat diepsee-organismes van die onderste sones minder vatbaar vir evolusie is as dié wat nader aan die oppervlak hou. ${ }^{6}$ ) Met ander woorde, ons vind ' $n$ verrassende ooreenkoms wat struktuurverhouding betref, tussen die bestaande oseaanlewe en die fossiele-patroon wat die aardlae openbaar. As daar nou in ag geneem word dat die paleontologie sy lewenspatroon hoofsaaklik grond op verstorwe lewe van eertydse oseane, omdat by verre die meerderheid fossiele dié van see-lewe is, ${ }^{7}$ ) word die ooreenkoms nie net verrassend nie, maar ook verklaarbaar. Het verstening nie plaasgevind binne die onderskeie sones in die oseaan nie? As die seebodem weens 'n katastrofiese gebeurtenis (of selfs 'n geleidelike proses) met die een of ander materiaal bedek sou word, sou alle lewe binne die onderste sone of sones vasgevang word, terwyl moontlike oorlewendes na dieper water sal moet terugval. Die volgende, hoër, sone 
vorm dan weer die laagste stratum direk bo die seebodem, en so kan die proses herhaal word totdat die see heeltemal opgevul is, sodat die oorblyfsels van die ingewikkeldste of „hoëre" lewensvorme naby aan die oppervlak gevind sal word. Omdat die laaste oorblyfsels van oseane moerasse sal wees, lê dit voor die hand dat fossiele van amfibiese herkoms nog bokant die boonste laag seediere gevind sal word. Miskien verklaar dit ook die verskynsel dat sommige van die lae sulke groot hoeveelhede en verskeidenheid organismes bymekaar bevat.

Ons sal dan by aanskouing van die verstorwe argiefstukke nie in die eerste plaas van verskil in ouderdom praat nie, maar van verskil in diepte. Fossiele in die onderste lae sal nie soseer behoort tot 'n vroeëre tydperk nie as tot 'n dieper waterstratum. Dat laasgenoemde ook ouer kan wees, spreek vanself, maar hierdie ouderdom kan wissel van dae tot 'n millenium of meer. Die noodsaaklikheid van soveel miljoene jare verval dan tesame met die noodsaaklikheid van genetiese verband of algemene evolusie.

Om hierdie teorie te toets sal eintlik rekondisionering en 'n radikaal oorspronklike benadering verg, want alle feitebronne, geologies en paleontologies, is gebaseer op die grondslag van ouderdom en die vooropstelling van langsame prosesse, terwyl 'n teorie soos hierdie eerder afhanklik is van 'n katastrofe-beskouing. Laat ons net na enkele voorbeelde verwys.

\section{Voorbeelde}

1. Prof. Lever verklaar op bladsy 75 van sy reeds aangehaalde werk dat weens afwesigheid van oorgangsvorme die „belangrikste argument" ten gunste van evolusie die feit is dat daar 'n parallelliteit soms waargeneem word tussen die opvolging van die optrede van nuwe klasse en die veranderde anatomiese bou.

Uit 'n diepte-standpunt is so 'n verskynsel 'n vanselfsprekendheid, uant die bevinding is dat die seelewe van onder na bo steeds ingewikkelder anatomiese bou openbaar. Ons hoef dus nie te doen te hê met kronologiese opvolging nie, dog slegs met tydgenootlike dieptelewe.

2. Die verrassende ontdekking van 'n lewende selakantide 'n aantal dekades gelede was 'n geweldige weerspreking van die natuurwetenskaplike standpunt. Hierdie „hoogs ge- 
vorderde" vis, wat al begin "pote" ontwikkel het in plaas van vinne, is ooreenkomstig evolusie-opvatting veronderstel om 'n vlakwatervis te gewees het wat 200 miljoen jaar gelede reeds verdwyn het. Dit blyk toe dat hy nòg verdwyn het nòg 'n vlakwatervis is. Hy word in die diepsee aangetref. Wat as 'n geologiese laag van 200 miljoen jaar ouderdom beskou is, blyk nou slegs 'n bepaalde diepte in die oseaan te wees!

3. Daar bestaan ' $n$ dualisme op stratigrafiese gebied. Die idealistiese rigting, wat hom besig hou met die geskiedenis van die aarde, trek die grenslyne van tydeenhede op ander plekke as die praktiese rigting, wat hoofsaaklik te doen het met die litologiese karakter van rotslae. Wanneer tydindelings gemaak word, word van fossiele as maatstaf gebruik gemaak, en val die grense saam met bio-stratigrafiese eenhede en nie rotseenhede nie. Met ander woorde, daar is geen parallelliteit tussen tyd-indeling en rotsformasie nie. So byvoorbeeld deursný die veronderstelde grens tussen die Cambrium- en die Ordovicium-sisteem in die Opper-Mississippi-vallei die Jordansandsteenformasie, terwyl 'n biostratigrafiese eenheid (gedefinieer op grond van sy fossiele-inhoud), genoem die Saukia, 'n gedeelte van die Franconia-, die hele St. Lawrence- en ' $n$ gedeelte van die Jordan-formasie omvat.

In artikel 19 (e) van die Amerikaanse Stratigrafiese Kode word hierdie onafhanklikheid van mekaar as volg beklemtoon: „Biostratigraphic units are fundamentally different from rock-stratigraphic units. The boundaries of the two may coincide or lie at quite different stratigraphic horizons or cross each other".

Ten opsigte van hierdie dualisme merk Krumbein op: "If time-stratigraphic units are 'practical' rather than 'ideal', it is natural that their application to the classification of any column of sediments tends increasingly to become a matter of pragmatism, with concomitant loss of significance in chronology. In terms of practicality, rock unit boundaries are easier to recognize and follow than biostratigraphic limits. As a result, the 'practical' limits of time-stratigraphic units are commonly transferred from their defining paleontologic boundaries to a convenient lithic contact, even where the rock units involved suggest no evidence of parallelism with synchronous surfaces".8)

Hierdie dualisme onderstreep 'n opvallend onlogiese situasie. Die eersgenoemde rigting aanvaar as maatstaf progressie- 
we verandering van organismes. Watter faktore so 'n verandering teweeggebring het, is wel nog onbekend, maar dat aanpassing by klimatologiese en omgewingsfaktore ' $n$ belangrike, selfs oorheersende bydrae gelewer het, is as feit aanvaar toe die geologiese tydperke in terme van miljoene jare bepaal is. Mens sou dus verwag dat sulke radikale veranderinge in die organiese natuur sy teenhanger sou hê in die anorganiese natuur ten opsigte waarvan die aanpassing juis moes geskied het. In plek daarvan vind ons 'n geleidelike, konstante proses van rotsvorming met 'n homogene struktuur wat dwarsdeur die organiese grens heenloop totdat dit ewe plotseling beëindig word. Dit dui tog op geredelike konstante omgewings- en klimatologiese faktore met 'n radikale omkeringspunt êrens binne in die organiese proses!

Met tydperke in terme van biologiese verandering skyn die litologiese veranderinge dus in geen verband te staan nie. Dit moet tog 'n eersterangse vraagstuk vir die geologie skep wanneer uitgegaan word van sulke botsende maatstawwe ter wille van 'n kronologiese beginsel.

Indien daar ' $n$ in-die-ooglopendo verband sou bestaan het tussen biologiese grense en rotsformasies, kon daar vir so 'n teorie nog iets te sê gewees het.

Roep dit dan nie reeds om 'n revolusionêre herwaardering van die beskikbare gegewens nie?

Wanneer diepte in plaas van tyd die uitgangspunt vorm is daar geen dergelike vraagstuk nie, want waaraan die versteningsproses ook al toegeskryf word - geleidelike of katastrofiese gebeurtenisse - die litologiese grens kon saam of buite enige van die biologiese oseaansones geval het.

Dat so 'n siening ook sy vraagstukke vir die verskillende natuurwetenskappe sal hê, word geredelik toegegee. Maar as die één groot toegewing uit die staanspoor gedoen word, naamlik dat alle bevindinge binne die geologie en paleontologie vir die afgelope honderd jaar - met hul probleme en al gemaak is binne die gedagtepatroon van kronologiese opeenvolging in terme van miljarde jare, dan is dit miskien tog die moeite werd om die voorgestelde uitgangspunt onbevooroordeeld te ondersoek en vas te stel in hoever ons nie maar net met skynvraagstukke te doen het nie.

Dit kan met soveel groter vrymoedigheid onderneem word wanneer ons eerstens in gedagte hou dat die evolusie-opvatting steeds met meer in plaas van minder vraagstukke te doen kry 
tot so 'n mate selfs dat evolusie-denkers in steeds wyer kringe die idee dat die mens van dierlike oorsprong is, laat vaar; en tweedens, dat 'n steeds meer kritiese standpunt ingeneem word teenoor die uitgangspunt van Lyell en sy volgelinge, soos o.a. blyk uit die reeds aangehaalde stellings van dr. Newell.

Indien daar dus Christen-wetenskaplikes op die gebied van die betrokke vakwetenskappe is wat bereid is om revolusionêr genoeg te dink om alle gegewens op hierdie grondslag te rekonstrueer, mag hulle 'n onberekenbare diens aan sowel die natuurwetenskap as die teologie bewys.

N. G. S. van der Walt.

Vermaas.

1) Prof. J. Lever: Creatie en Evolutie, p. 77.

2) W. C. Krumbein and L. L. Sloss: Stratigraphy and Sedimentation, p. 40.

3) p. 29.

4) Newsweek, $23 / 12 / 63$, p. 48 .

5) Krumbein, p. 13.

6) Vassilief and Gouschev: Life in the Twenty First Century.

7) Henry Woods, in sy Palaeontology, p. 1, beklemtoon hierdie feit as volg: „Now since there are comparatively few places on land where material is being deposited to any great extent, it follows that terrestrial animals will stand but little chance of being preserved... such instances are of comparatively rare occurance".

8) p. 42. 